\title{
Availability and Adequacy of Resources for Entrepreneurship Education in Universities in South-East, Nigeria
}

\author{
Dr. Emeka A. Nwachukwu \\ Chima Uzoma Okpo \\ Ebonyi State College of Education Ikwo. \\ Nigeria
}

\begin{abstract}
The study investigated the availability and adequacy of resources for entrepreneurship education in universities in the South-East Zone of Nigeria. It was guided by three research questions and three hypotheses all derived form the purpose of the study. The study was carried out as a survey. Two hundred and eighty two respondents were utilized consisting (10) ten directors of academic planning, (10) ten Directors/ Co-ordinators entrepreneurship and (262) two hundred and sixty two lecturers. The instrument used for data collection was a set of researchers' constructed rating scale and checklist. Data were analyzed using mean statistics to answer the research questions and Hypotheses one and two were tested using one way ANOVA while hypothesis three was tested using Chi Square $\left(X^{2}\right)$ test via SPSS version 20 at 5\% level of Significance. The findings showed among others that adequate funds were not available for undertaking the programme. Some universities do not have separate building fo entrepreneurship coupled with insufficient computers, and lack of adequate workshop. As a result of the findings made on this study, it was recommended among others that government should make available adequate funds for entrepreneurship education. Universities should separate entrepreneurship education fund from their allocation.
\end{abstract}

\section{Background to the Study}

Education has played a significant role in uplifting the standard of living of nations across the world. It has also contributed to all facets of development of these nations. Consequently, nations of the world have recognized education as a veritable tool for effective national development. Nigeria like other African countries is faced with challenges of globalization and trade liberalization. It is common in Nigerian education landscape that objectives of specialized education are not translated into practical realities during the process of policy implementation (Okebukola, 2004, Onyeachu. 2008).

The Nigerian government in her effort to ensure job opportunities for students after graduating from the universities established a compulsory entrepreneurship education course. With this knowledge, students can set up small business enterprise rather than remain jobless for a long period after graduation. This reflect in Nigerian's National Policy on education which states that education is the most reliable instrument for propelling change, as no fundamental change can occur in any society except through educational/evolution that impact on the intellect (Federal Government of Nigeria, 2013).

Adejimala and Olufunmilayo (2009) reported that about $80 \%$ of Nigerian graduates from Nigerian Universities find it difficult to get employment every year. This is partly due to the curricula of Universities and other tertiary institutions which lay much emphasis on training for white collar jobs. Another problem of Nigerian education programmes, however, is that there is too much emphasis on the value of certificate rather than the holder himself. In other words, undergraduates struggle hard to attain a global cheat which is the certificate rather than skill which could make them self-reliant.

Okojie (2008) affirms that our educational programmes lay much emphasis on theories rather than the combination of theories and practical. Hence, it is hoped that government should encourage diversification of economy through adequate support for private establishment and practical acquisition of skill in higher institutions. Graduate unemployment and under employment have resulted in youth restiveness, vices and insecurity of lives and property. When the youth are gainfully employed all these vices will be a thing of the past. 
This will be made possible when the resources required for teaching entrepreneurship education at the universities is available and, adequate.

The National University Commission (NUC) through the presidency in 2006 directed that entrepreneurship education be obligatory for every university student for at least two semesters in course of-.Diversity career. The NUC further directed the full take off of the programme for all the universities to be completed by 2007/2008. The NUC further calls for list of problems so far encountered in the running of the programme to be forwarded on or before one week of receipt of the letter.

This goes to lay emphases on the importance the Federal Government attaches to entrepreneurship studies in higher institutions. NUC furthermore organized a two day workshop (May 21 and 22, 2008) for Vice Chancellors to sensitize them on this issue. Adah, (2008) further enumerated the aims of entrepreneurship education in tertiary institutions as follows:

1. Providing meaningful education to the youth to be self employed and self reliant.

2. Providing graduate with enough skills that will make them to be creative and innovative in identifying new business opportunities.

3. Providing graduates with enough training in risk management, to make uncertainty bearing more possible and easy to give young graduates training to establish a career in small and medium scale business etc.

Entrepreneurship education was introduced at tertiary level of education with the aims of making students acquire specific skills notwithstanding their area of study. In some institutions, they are introduced at 200 and 300 levels as (GST) General Studies. The effective implementation of this course in universities in the South-East Zone requires human resources and material resources.

A resource can be defined as a useful or valuable possession or means of support for man in making a living. Resources in the universities for entrepreneurship education consist of human resources, material resources and financial resources. Human resources consist of lecturers, ancillary staff, their preparations, upgrading, motivation and professional commitment. Anwor (2002) and Oboegbulam (2003) opine that without competent teaching staff and adequate material resources, a well-funded functional education system will fall below expectation. At the center of implementation of entrepreneurship education are the lecturers, their quality and quantity are crucial to the achievement of the programme.

However, going by National University Commission (NLJC) academic structure requires to produce quality graduates and most universities fell short of the requirements. Most of the entrepreneurship lecturers are not specialist in these fields and due to the fast nature of setting up of these programme, most of the Lecturers in the department, had to be involved (Okwudibia, 2010).

Izuagba (2010) ,Ekwueme, Ofolia, Uchegbu, Anyikule and Nkemdilom (2009), confirmed lack of qualified specialist entrepreneurship teachers for the programme. Skillful Personnel are required to perform most of the skills, such personnel that specialized in one skill or the other as to enable them carry out the practical aspects.

On the other hand, entrepreneurship material resources such as infrastructure includes: Laboratories: where practical are carried out. Libraries: Good functional and E-Library to enable students update their knowledge. Building: classrooms, hostels, lecturers' offices for conducive learning environment, machineries, which may be utilized in one way or the other.

Certain gadgets like computers cannot be operated due to epileptic supply of power. All Information Communication Technology (1CT) tools for entrepreneurship education depend heavily on steady supply of energy if they are to function effectively. The facilities available do influence, to a large extent the quality of entrepreneurship education being provided. Funds are necessary in any administration, it aids in providing all the necessary materials needed in a system. The University cannot perform optimally without funding in its entire administrative ramification. Ayibola (2008) notes that, no organization functions effectively without funds: The issue of poor funding has its manifestations in problems such as shortage of academic staff, scarcity of library books and journals, dilapidated building and archaic equipment. Izuagba (2010) observed that "the education industry is usually the first and easiest victim of budget-cuts during reforms". Also Ayodele (2006) identified inadequate capital to be one of the principle factors hindering entrepreneurship education in the country. Hence the researchers investigated availability and adequacy of resources for entrepreneurship education in universities in the South-East Zone of Nigeria.

\section{Statement of the Problem}


In excess of the years, the implementation of entrepreneurship education has been in uncertainty to the public and as it concerns universities in the South-East Zone.

The state of worry ranges from the aspect of the tact that despite the compulsory entrepreneurship education in the Universities, many graduates are still made redundant for a long time after graduation. The entrepreneurship education delivered to undergraduates at 200 levels seems not to be meeting the objectives for the unavoidable course as a general studies course. The content delivery and management of the course seems to be porous. There is sky-scraping failure rate and many students struggle for a minimum pass mark of $40 \%$.

One then wonders why the problem of unemployment is still lingering. Now that this laudable course of entrepreneurship education programme has been mounted in the Universities for job creation and skills, the problem of unemployment is still ravaging the society. One may ask if these problems are as a result of resource availability or adequacy in the Universities. This research work therefore focuses on availability and adequacy of resources for entrepreneurship education in Universities in South-East, Nigeria.

\section{Scope of the Study}

This study covered all the coordinators with their lecturers in the public Universities in South-East of Nigeria. It is on the availability and adequacy of resources for entrepreneurship education. Its content scope focused on finding out the availability and adequacy of fund, availability and adequacy of lecturers and the availability and adequacy of facilities. This study was based on personal observations and ratings of the Directors of Academic Planning, Coordinators of entrepreneurship Programme and Lecturers of entrepreneurship education.

\section{Purpose of the Study}

The main purpose of this study is to ascertain the availability and adequacy of resources for entrepreneurship education in the universities in the South-East Nigeria. Specifically, the study sought to:

1. Ascertain the adequacy of fund for entrepreneurship education in south-east of Nigeria.

2. Find out the adequacy of lecturers for entrepreneurship education in Universities in southeast Nigeria.

3. Determine the adequacy of facilities for entrepreneurship education in Universities in south-east, Nigeria.

\section{Research Questions}

The following research questions will guide the study:

1. What are the mean rating scores of Directors of Academic Planning, Directors/Coordinator of entrepreneurship education and Lecturers of entrepreneurship education in the Universities on the adequacy of fund?

2. How adequate are the available lecturers for entrepreneurship education in Universities in South-East of Nigeria?

3. How adequate are the available facilities for entrepreneurship education in Universities in South-East of Nigeria?

\section{Hypotheses}

The following null hypotheses are formulated and will be tested at 0.05 level of significance

Ho: : There is no significant difference between the mean rating scores of Directors of Academic Planning, Directors/Coordinator of entrepreneurship education and Lecturers of entrepreneurship education in the Universities on availability of fund.

Ho$_{2}$ : There is no significant difference between the mean rating scores of Directors of Academic Planning Directors/Coordinator of entrepreneurship education and lecturers of entrepreneurship education in the Universities on the adequacy of fund.

Ho3: The number of available lecturers for entrepreneurship education of federal and state Universities is not significantly dependent on gender.

\section{Review of Related Literature}

\section{Conceptual Framework: Entrepreneur/ Entrepreneurship}

The term entrepreneur was originally a loan word from French and was first defined by an Irish -French economic Richard Cantillon. Entrepreneur in English term applied to a person who is willing to help launch a new venture or enterprise and accept full responsibility for the outcome. In the words of Alumode and Nwite (2009) 
entrepreneur is one who organizes, manages and assumes the risk of a business with the sole aim of maximizing profit. According Schumpter (2011) entrepreneur is defined as a process of searching out opportunities in the market place and arranging resources required exploiting these opportunities and assumptions. On the other hand, Ojeifo (2012) defined an entrepreneur as the owner or manager of business enterprise who through risks and initiative, attempts to make a profit.

Entrepreneurship, on the other hand, is the process by which an individual or a group of individuals use organized efforts and means to pursue opportunities to create value and growth by fulfilling wants and needs through innovation and uniqueness, no matter what resources are currently controlled (World Bank 2002).

\section{Entrepreneurship Education}

The Commission Communication (2006) defined entrepreneurship education as the individual ability to turn ideas into action. It includes creativity, innovation and risk taking as well as the ability to plan and manage projects in order to achieve objectives.

United Nation Educational, Scientific and Cultural Organization (UNESCO) (2008) stated that entrepreneurship education is made up of all kinds of experiences that give students the ability and vision of how to access and transform opportunities of different kinds.

However, Udofia and Nneji (2010.154) see "entrepreneurship education as a life- long education whereby people are exposed to opportunities to develop skills in business". Entrepreneurship education is an employment strategy that can lead to economic self sufficiency for people and their families with the potential.

The objectives of entrepreneurship education according to Paul (2005) are structured to achieve the following:

i. To offer functional education for the youth that will enable them to be self-employed and self-reliant.

ii. Provide the youth graduates with adequate training that will enable them to be creative and innovative in identifying novel business opportunities.

iii. To serve as a catalyst for economic growth and development.

iv. Offer tertiary institution graduates with adequate training risk management to make certain bearing feasible,

v. To reduce high rate of poverty and create employment generation as well as reduction in rural urban migration.

vi. To create smooth transition from traditional to modern industrial economy.

Correspondingly, UNESCO (2002.2), the purpose of Entrepreneurship education includes

i. Educating individuals for and about business,

ii. Providing a continuous programme of planned learning experience designed to equip individuals to fulfill effectively three roles.

iii. Providing and distributing goods and services as workers,

iv. Using the product as consumers, and making wise socio-economic decision.

\section{Entrepreneurial Skills}

A skill is an asset to the individual in that he is invited to work or contribute his knowledge, wealth, experience, expertise or intelligence for a sustainable dynamic economy. Skills are the economic tools with which entrepreneurs confront and solve societal problems. Entrepreneurial skills according to the industrial training of Nigeria (ITF) as contained in Asodike (2007) defined it "as a combination of knowledge and practical ability. The skills of the entrepreneur are divided into three namely:

i. Personal skills (self confidence, motivation, savings and investment, planning, patience, belt-tightening, adaptation, communication, human relations).

ii. Technical/technological/engineering skills (vocational, analytical, psychomotor, creativity, artistic and numerical).

iii. Professional skills (membership to professional bodies, professional ethics, behaviour, self and professional respects skills of perfection and interconnectivity).

These definitions have activities which an individual or a group of associated individuals undertake to initiate, maintain or aggrandize a project oriented business unit for the purpose of production or distribution of economic goods or services.

\section{Concept of Resources}

A resource can be defined as a useful or valuable session or a means of support for man in making a living. Resource in this study, therefore, is taken to mean input into educational programme. Such resources according to 
Ugwu,(2005) fall into two categories namely human and material resources. Human resources centers mainly on lecturers, their preparations, upgrading, motivation and professional commitments; while the material resources consist of instructional materials like printed audio tapes, pictures, charts, projected media such as transparent projection and opaque projection. The infrastructures consist of structures in terms of buildings and equipments. Lastly are the funds that are needed in terms of money or physical cash.

Thus,for a worker to live up to expectation, such a worker must be motivated. The fulfillment of this role lies on funding and administering sound, functional educational policy.

\section{National Universities Commission Guidelines for Establishment of Entrepreneurship Education Study Center}

The National Universities Commission (NUC) Act No. 48, 1988 empowers the commission to lay down minimum standard for all programme taught in Nigerian Universities (Okafor and Onwumere, 2012).

In 2001 a benchmark was established for each programme in all the discipline taught in Nigerian Universities Okafor and Onwumere, 2012). In the area of entrepreneurship education the benchmark are as follows:

1. Building Construction: Construction of a separate building block or renovation of existing ones that will accommodate at least 50 students and personnel at a given time.

2. Equipment: The centre should be equipped to standard that will make training more meaningful,

3. Budget; Allocation for running the centers.

Instructions fully guided processes by the training manuals as provided. Library facilities: N.U.C. Guideline for establishment of Entrepreneurship Education Study Centre. The National Universities Commission (NUC) (Act) No. 481988 empowers the Commission to lay down minimum standard for all programme taught in Nigerian universities. In 2001 a benchmark was established for each programme in all the discipline taught in Nigerian universities. Today most of the universities in the $\mathrm{S} / \mathrm{E}$ have mounted the programme.

\section{Theoretical Framework:}

\section{Need for Achievement Theory (NAT)}

This is a psychological theory of David MC Clelland (1965) which shows the functionality of strong relationship between need for achievement (n-Achievement), economic development and entrepreneurial activities. The proponent of the theory -Me Clelland (1965), explains that there would be a relatively greater amount of entrepreneurial activities in the society, where the average level of need achievement is relatively high. People who are achievement motivated typically prefer to master a task or situation.

The motivational need stems from a person's desire to influence, teach, or encourage others. The importance of the theory is that when students/learners are sufficiently motivated have high need for achievement in life through entrepreneurship education, there is greater tendency for them to set up their own business after graduation.

\section{Review of Empirical Studies}

Osarenren-Osaghae and Irabor (2012) assessed the availability and adequacy of human and material resources for the teaching and learning of skill-based courses in Nigerian public Universities. In doing this, three (3) research questions and two (2) hypotheses were formulated. The population of this study consisted of academic staff and final year students of 2009/2010 academic session in Nigerian Public Universities. The instruments used to collect data were the questionnaire checklist. The researcher personally visited the ten (10) institutions that were earlier selected through stratified random sampling, and administered questionnaires to the respondents numbered 1750 but only 1500 were returned. Data was analyzed using the mean statistics, percentage and t-test, amongst other findings was that: the human and material resources on ground for the teaching and learning of ill-based courses in Nigerian Public Universities did not match a minimum standard requirement recommended by the National Universities Commission. Based on these findings, recommendations such as government, non-government organization and good citizens should ensure to provide the needed human and material resources to help in the production of skilled graduates for national development were made amongst others, hopefully when adhered to, would yield positive results.

\section{Method}


This study adopted a survey design. The study is carried out in Universities within the South-East, Nigeria. The Population of the study consists of two hundred and eighty-two (282) respondents. This is made up of all Directors of Academic Planning (10), Coordinators of Entrepreneurial Programme(10) and 262 Lecturers of Entrepreneurship Education in all the government owned Universities in South East Zone of Nigeria.

The study made use of all the population, hence there is No sample size.

The instruments for data collection is a self constructed checklist prepared by the researchers in line with the guidelines from NUC and a self constructed rating scale prepared by the researchers in relation to the NUC stated guideline. The checklist was used to observe the adequacy of lecturers, funds and facilities for teaching of entrepreneurship education in universities in the South-East Geo-Political Zone of Nigeria. The checklist is named "Availability and Adequacy of Resources for Entrepreneurship Education Scale" (AAREES). It consists of two sections, A \& B. Section A is designed to elicit personal information about the respondent while section B contains 10 items which focus on eliciting information on adequacy of fund for entrepreneurship education in Universities in the South-East zone of Nigeria as rated by the Directors of Academic Planning, Coordinators/Directors of entrepreneurship education and lecturers of entrepreneurship education. The options of the responses for research question one was based on four points checklist of Strongly Agree (SA), Agree (A), Disagree (D)and Strongly Disagree (SD), while that of research question two was based on Very Adequate (VA), Adequate (A), Inadequate (I), and Very Inadequate (IV). Each of the responses was given a value shown below. Strongly Agree $(\mathrm{SA})=4$; Agree $(\mathrm{A})=3$; Disagree $(\mathrm{D})=2$; Strongly Disagree $(\mathrm{SD})=1$; Very Adequate (VA) 4, Adequate (A)3; Inadequate (1)2 Very Inadequate (VI)1.

Face validity of the instrument was determined by four (4) experts - two (2) from the department of Arts Education, Ebonyi State University, Abakaliki; and two (2) from the Department of Measurement and Evaluation of the same University.

The reliability of the instrument was also determined by administering the instrument to 40 respondents from Universities in south-south zone with the help of three research assistants. Cronbach- alpha statistics was used to determine the internal consistency of the instrument.

The researchers' adopted direct Delivery Method in collecting their data. Finally, research questions were answered using frequency counts and means. Mean scores of 2.50 and above were seen as agreed and adequate while below 2.50 were seen as disagreed and inadequate. Hypotheses one and two were tested using one way ANOVA while hypothesis three was tested using Chi Square $\left(X^{2}\right)$ test via SPSS version 20 at 5\% level of significance.

\section{Result Analyses and Presentation}

Research Question one:What are the mean rating scores of Directors of academic Planning, Coordinators/ Directors of entrepreneurship education and Lecturers of entrepreneurship education in the University on the adequacy of fund?

Table 1: Mean rating scores of Directors of Academic planning, Coordinators/Directors of entrepreneurship education and Lecturers of entrepreneurship education in the universities on the adequacy of fund.

\begin{tabular}{|l|l|l|l|l|l|l|l|l|l|l|}
\hline & \multicolumn{2}{|c|}{$\begin{array}{l}\text { Directors of Academic Planning } \\
\text { N=10 }\end{array}$} & \multicolumn{2}{l|}{ Coordinators/ Directors N=10 } & \multicolumn{2}{l|}{$\begin{array}{l}\text { Lecturers } \\
\text { N=262 }\end{array}$} \\
\hline 1 & $\begin{array}{l}\text { Item Statement: Fund } \\
\text { are: }\end{array}$ & $\mathbf{X}$ & $\mathbf{S D}$ & Decision & $\mathbf{X}$ & $\mathbf{S D}$ & Decision & $\mathbf{X}$ & SD & Decision \\
\hline 2 & $\begin{array}{l}\text { Adequate to purchase } \\
\text { instructional materials }\end{array}$ & 1.50 & 0.33 & Disagreed & 1.50 & 0.17 & Disagreed & 1.55 & 0.12 & Disagreed \\
\hline 3 & $\begin{array}{l}\text { Enough to take students } \\
\text { to industries for training }\end{array}$ & 1.20 & 0.31 & Disagreed & 1.30 & 0.45 & Disagreed & 1.50 & 0.19 & Disagreed \\
\hline 4 & $\begin{array}{l}\text { Adequate to maintain } \\
\text { facilities }\end{array}$ & 1.90 & 0.19 & Disagreed & 2.10 & 0.48 & Disagreed & 1.42 & 1.19 & Disagreed \\
\hline 5 & $\begin{array}{l}\text { Enough to provide } \\
\text { steady power supply }\end{array}$ & 1.90 & 0.12 & Disagreed & 1.70 & 0.61 & Disagreed & 1.66 & 0.17 & Disagreed \\
\hline 6 & $\begin{array}{l}\text { Sufficient to manage the } \\
\text { staff }\end{array}$ & 1.50 & 0.15 & Disagreed & 1.60 & 0.16 & Disagreed & 1.65 & 0.29 & Disagreed \\
\hline & Cluster Mean & $\mathbf{1 . 6 0}$ & & & $\mathbf{1 . 6 4}$ & & & $\mathbf{1 . 5 6}$ & & \\
\hline
\end{tabular}


Table1 shows the mean rating scores of Directors of academic Planning, Coordinators/Directors of entrepreneurship education and Lecturers of entrepreneurship education in the Universities on the adequacy of fund. The table indicated that all the items in the table $(1,2,3,4$ and 5) were disagreed by (the three groups of respondents because, their mean scores were below the criterion mean of 2.50. the cluster mean of 1.60, 1.64 and 1.56 for the three groups (Directors of Academic Planning, Coordinators/Directors and Lecturers) respectively confirms the disagreement of the respondents concluding that there no adequate fund for the purchase instructional materials, to take students to industries for training, maintain facilities, provide steady power supply and manage the staff for entrepreneurship education.

Research Question two: How adequate are the available lecturers for entrepreneurship education in universities in South-East Geo-Political Zone of Nigeria?

Table 2: Adequacy of the available lecturers for entrepreneurship education in universities in South-East Geopolitical Zone of Nigeria

\begin{tabular}{|l|l|l|l|l|}
\hline $\mathbf{s} / \mathbf{n}$ & Universities & Gender & Total \\
\hline 1. & IMSU (State) & 71 & 27 & Inadequate \\
\hline 2 & FUTO (Federal) & 32 & 30 & Inadequate \\
\hline 3 & ABUS(state) & 90 & 25 & Inadequate \\
\hline 4 & MUAU(Federal) & 15 & 25 & Inadequate \\
\hline 5 & NAU(Federal) & 36 & 28 & Inadequate \\
\hline 6 & ANSU(State) & 15 & 25 & Inadequate \\
\hline 7 & ESUT(state) & 30 & 26 & Inadequate \\
\hline 8 & UNN(federal) & 46 & 30 & Inadequate \\
\hline 9 & EBSU(state) & 11 & 24 & Inadequate \\
\hline 10 & FUNAI (federal) & 25 & 22 & Inadequate \\
\hline Total & & $\mathbf{3 7 1}$ & $\mathbf{2 6 2}$ & Inadequate \\
\hline
\end{tabular}

Table 2 shows the adequacy of the available lecturers for entrepreneurship education in universities in South-East Geopolitical Zone of Nigeria. The table revealed that in all the 10 state and federal universities in South-East GeoPolitical Zone of Nigeria, the entrepreneurship lecturers are inadequate compared to the number of students and number of departments and faculties in the universities. The adequacy of the lecturers was measured based on the NUC guideline that stipulated that 50 computers for 50 students in the entrepreneurship block per a lecturer. Therefore going by the number of departments and faculties in each university, the following decision were reached:

Research Question three: How adequate are the available facilities for entrepreneurship education in universities in South-East Geo-political Zone of Nigeria?

Table 3: Adequacy of the available facilities for entrepreneurship education in universities in South-East Geopolitical Zone of Nigeria

The adequacy of the available facilities was determined following the stipulated N.U.C. guideline and also comparing the need of its users

\begin{tabular}{|c|c|c|c|c|c|c|c|}
\hline $\mathrm{s} / \mathrm{n}$ & Adequacy of facilities & \multicolumn{3}{|c|}{ State universities } & \multicolumn{3}{|c|}{ Federal universities } \\
\hline 1 & $\begin{array}{l}\text { Entrepreneurship block } \\
\text { with } 50 \text { students } \\
\text { capacity hall }\end{array}$ & 5 & 3 & inadequate & 5 & 4 & Inadequate \\
\hline 2 & Workshop & 5 & 3 & inadequate & 5 & 4 & Inadequate \\
\hline 3 & $\begin{array}{l}\text { Computers at least } 50 \text { in } \\
\text { the block }\end{array}$ & 250 & 50 & Inadequate & 250 & 250 & Adequate \\
\hline 6 & Internet facilities & 5 & 5 & Adequate & 5 & 5 & Adequate \\
\hline 7 & Workshop machineries & 10 & 10 & Adequate & 10 & 20 & Adequate \\
\hline 8 & $\begin{array}{l}\text { Library block for } \\
\text { entrepreneurship education }\end{array}$ & 5 & 3 & Inadequate & 5 & 5 & Adequate \\
\hline 9 & Toilet facilities & 5 & 1 & Inadequate & 5 & 5 & Adequate \\
\hline 10 & Lecturers offices & 20 & 10 & Inadequate & 20 & 18 & Inadequate \\
\hline
\end{tabular}


Table 3 shows that adequacy of the available facilities for entrepreneurship education in universities in South-East Geopolitical Zone of Nigeria. The table revealed that in the state universities, projectors, VCR, internet facilities and workshop machineries are adequate while entrepreneurship bloc, computers, workshops etc are inadequate. In the federal universities, only facilities like entrepreneurship block, workshops and lecturers ${ }^{7}$ offices are inadequate while the others like computers, projectors, VCR, internet facilities, workshop machineries and toilet facilities are adequate.

\section{Testing of Hypotheses Hypothesis One}

Ho1: There is no significant difference between the mean rating scores of Directors of Academic Planning, Coordinators/Directors of entrepreneurship education and Lecturers of entrepreneurship education in the universities on the availability of fund.

Table 4: One way ANOVA summary table of the significant difference between the mean rating scores of Directors of Academic Planning, Coordinators/Directors of entrepreneurship education and Lecturers of entrepreneurship education in the universities on the availability of fund.

Summary of One Way ANOVA Table

\begin{tabular}{|l|l|l|l|l|l|l|}
\hline ANOVA & $\begin{array}{l}\text { Sum of } \\
\text { squares }\end{array}$ & $\begin{array}{l}\text { Degree of } \\
\text { freedom }\end{array}$ & Mean squares & $\mathbf{F}_{\text {calc }}$ & $\mathbf{F}_{\text {tab }}$ & Decision \\
\hline Between group & $\mathbf{0 . 0 3 0}$ & $\mathbf{2}$ & $\mathbf{0 . 0 1 5}$ & & & \\
\hline Within group & 1.215 & 12 & 0.101 & 0.150 & 3.89 & $\begin{array}{c}\text { Accept } \\
\text { Ho }\end{array}$ \\
\hline Total & 1.245 & 14 & & & & \\
\hline
\end{tabular}

Table 4 shows the one way ANOVA summary table of the significant difference between hemean rating scores of Directors of Academic Planning, Coordinators/Directors of entrepreneurship education and Lecturers of entrepreneurship education in the universities on the availability of fund. It was indicated in the table that the degree of freedom total is 14 , $\mathrm{f}$-calculated is 0.150 while the f-tabulated is 3.89 at $5 \%$ level of significance, the $\mathrm{f}$ calculated is less than the f-tabulated leading to the acceptance of the null hypothesis and concluding that there is no significant difference between the mean rating scores of Directors of Academic Planning, Coordinators/Directors of entrepreneurship education and education in the universities on the adequacy of fund. It was indicated in the table that the degree of freedom total is 14 , $\mathrm{f}$-calculated is 0.141 while the $\mathrm{f}$-tabulated is 3.89 at $5 \%$ level of significance, the f-calculated is less than the f-tabulated leading to the acceptance of the null hypothesis and concluding that there is no significant difference between the mean rating scores of Directors of Academic Planning, Coordinators/Directors of entrepreneurship education and Lecturers of entrepreneurship education in the universities on the adequacy of fund.

\section{Hypothesis Two}

$\mathrm{Ho}_{2}$ : There is no significant difference between the mean rating scores of Directors of Academic Planning, Coordinators/Directors of entrepreneurship education and Lecturers of entrepreneurship education in the universities on adequacy of fund.

Table 5: One way ANOVA summary table of the significant between the mean rating scores of Directors of Academic planning, Coordinators/Directors of entrepreneurship education and Lecturers of entrepreneurship education in the universities on the adequacy of fund

Summary of One Way ANOVA Table

\begin{tabular}{|l|l|l|l|l|l|l|}
\hline ANOVA & $\begin{array}{l}\text { Sum of } \\
\text { squares }\end{array}$ & $\begin{array}{l}\text { Degree of } \\
\text { freedom }\end{array}$ & Mean squares & F $_{\text {calc }}$ & F tab & Decision \\
\hline Between group & $\mathbf{0 . 0 1 8}$ & $\mathbf{2}$ & $\mathbf{0 . 0 0 9}$ & & & \\
\hline Within group & $\mathbf{0 . 7 5 3}$ & $\mathbf{1 2}$ & $\mathbf{0 . 0 6 3}$ & $\mathbf{0 . 1 4 1}$ & $\mathbf{3 . 8 9}$ & $\begin{array}{c}\text { Accept } \\
\text { Ho }\end{array}$ \\
\hline Total & $\mathbf{0 . 7 7 1}$ & 14 & & & & \\
\hline
\end{tabular}

Table 5 shows the one way ANOVA summary table of the significant difference between the mean rating scores of Directors of Academic Planning, Coordinators/Directors of entrepreneurship education and Lecturers of entrepreneurship education in the universities on the adequacy of fund. It was indicated in the table that the degree 
of freedom total is 14 , f-calculated is 0.141 while the f-tabulated is 3.89 at $5 \%$ level of significance, the fcalculated is less than the f-tabulated leading the acceptance of the null hypothesis and concluding that there is no significant difference between the mean rating cores of Directors of Academic Planning, Coordinators/Directors of entrepreneurship education and lecturers of entrepreneurship education in the universities on the adequacy of fund.

\section{Hypothesis Three}

$\mathrm{Ho}_{3}$ : The number of available lecturers for entrepreneurship education of federal and state universities is not significantly dependent on gender.

Table 6: Summary of $X^{2}$ table of the dependency of available lecturers' for entrepreneurship education of federal and state Universities on gender

\begin{tabular}{|l|l|l|l|l|l|l|}
\hline ANOVA & Universities & DF & $\mathbf{X}^{2}$ cal & $\mathbf{X}^{2}$ crti. & Decision \\
\hline Gender & States & Federal & & & & \\
\hline Male & $\mathbf{8 5}$ & $\mathbf{8 6}$ & $\mathbf{1}$ & $\mathbf{0 . 3 0 0}$ & $\mathbf{3 . 8 4 1}$ & Accept Ho \\
\hline Females & $\mathbf{4 2}$ & $\mathbf{4 9}$ & & & & \\
\hline
\end{tabular}

Table 6 above, illustrated the dependency of available lecturers for entrepreneurship education of federal and state universities on gender. The result showed that with 1 degree of freedom, at 0.05 level of significance, the calculated value of 0.300 is less than the tabulated/critical $\mathrm{X}^{2}$ value of 3.841 , hence concluding that the number of available lecturers for entrepreneurship education of federal and state universities is not significantly dependent on gender.

\section{Summary of Findings}

From the analyses, the following findings were made:

i. Funds are not provided from time to time, or disbursed to take care of unforeseen circumstances and also the funds were not available when needed to purchase necessary materials for entrepreneurship education and when made available it is very inadequate.

ii. The study revealed that entrepreneurship lecturers are inadequate compared to the number of students and number of departments and faculties in the universities.

iii. The number of available facilities in federal universities is more than the number in the state universities.

iv. There is no significant difference between the mean rating scores of Directors of Academic Planning, Coordinators/Directors of entrepreneurship education and Lecturers of entrepreneurship education in the universities on the adequacy of fund.

v. The number of available lecturers for entrepreneurship education of federal and state universities is not significantly dependent on gender.

\section{Discussion of Findings}

\section{Adequacy of Fund}

The study also revealed that there are no adequate funds for the purchase of instructional materials, to take students to industries for training, maintain facilities, provide steady powersupply and manage the staff for entrepreneurship education. Gabadeen and Raimi (2012) indicated that there is inadequate funding of entrepreneurship education, which has negatively affected the implementation of entrepreneurship education curricula, a fact attested to by National Universities Commission (NUC), National Board for Technical Education (NBTE) and National and sister supervisory agencies in Nigeria.

\section{Adequacy of the Available Lecturers}

The study also showed that the entrepreneurship lecturers are inadequate compared to the number of students and number of departments and faculties in the universities. Human resources are available in terms of quality and quantity. Although entrepreneurship education is entirely a new field of study that requires skills, there seem to be inadequate skilled human resources, since most of the lecturers and resource personnel are few in number compared to the number of students. The finding affirms the statement of Anwor (2002) and Oboegbulam (2003) that without competent teaching staff and adequate material resources, a well-funded functional education system 
will fall below expectation. Obeleagu and Moruku (2010) attested to poor state of Infrastructure in Nigerian Universities.

\section{Adequacy of the Available Facilities}

On the issue of adequacy, the study revealed that in the State Universities, Projectors, VCR, internet facilities and workshop machineries are adequate while entrepreneurship bloc, computers, workshops etc are inadequate. In the Federal Universities, only facilities like entrepreneurship block, workshop and lecturers offices are inadequate while the others like computers, projectors VCR, internet facilities are adequate. This however agrees with the words of Osarenren-Osghae and Irebor (2012) who discovered that the discrepancy between school workshop facilities and the actual work facilities may adequately account for the amount of retraining given to Nigerian University graduates before they can effectively perform in the industries.

\section{Recommendations}

Based on the findings of the study, the researchers recommended as follows:

1.Government should make available adequate funds for entrepreneurship education in the universities by separating the fund from university allocation as to give those involved free hand to utilize it well. Tertiary Education Trust Fund should allocate more funds to entrepreneurship education.

2. Adequate facilities should be provided to both the state and federal owned universities by the government.

3. Directors/Co-coordinators' of entrepreneurship education should develop curriculum for the programme, set up centers where practical application should be put in full production as to sell out their product(s) to generate enough funds than depending on government always.

4. There should be adequate awareness campaign to sensitize the citizenry on the benefits of entrepreneurship education as well as create skill acquisition centers in the schools.

\section{References}

Abiri, K. \&Jekayirtfa, A. (2008). Perspectives on the history of education in Nigeria. Ibadan: Emola Jay Communications Inc.

Adah, O.C. (2008): Entrepreneurship education: Problems and prospects. Kaduna: Greeks Printing Press.

Adejimale, A.S. and Olufunmilayo, T. (2009): Spinning off an entrepreneurship culture among Nigerian University Students; prospects and challenges. African Journal of Business Management, 9(3), 80 - 88.

Adeola, L. \&Oviavve, J.I. (2010). Strategies for Promoting Entrepreneurship education in secondary school curriculum. In Uoputaife, Maduewusi and Igbo (eds), Issues and Challenges In Nigerian Education In the $21^{x l}$ century. Onitsha: West and Solomon.

Adesina S. (1990): Educational management Enugu: Forth Dimension Pub. Co.

Ajagu, A, (2009, July 8), Poor Infrastructural in Nigeria. Vanguard, 25. Website www.Vanquardngr.com retrieved on 30 may 2014.

Ajibola, M. (2008): Innovation and Curriculum development for basic education in Nigeria policy priorities and challenges of practices implementation. Research Journal of international studies 8 November 51 - 59.

Akinbode, P.O. (2009): Perspectives on entrepreneurship and Skills Development of Federal Government Sevenpoint Agenda" A, paper presented at Entrepreneurship Workshop held at National Universities Commission, NUC.

Akpomi, M.E. (2009). Achieving millennium development goals through teaching of entrepreneurship education in Nigeria higher education institutions. European Journal of Social Science, 8(1): 152-159.

Alabi, T., Alanana, O.O. \&Bahal, M. (2014). Entrepreneurship education: A panacea to graduate unemployment in Nigeria. Journal of Sustainable Development in Africa, 16(4): 35-43.

Alain, J. and Hossan, M.A. (2003): Linking Between Franchising Networks for Entrepreneurship and Economic Development -Looking for a New Model. Paper Presented at the Emnet-Conference on Economics and Management of Franchising Networks, Vienna, Austria, June 26 - 23.

Alumode, B.E. \&Nwite, 0. (2009): "Managing Entrepreneurship Education for Sustainable Unemployment Alleviation" in J.B. Babalola, G.O. Akpa, N. Ikediugwu, A.O. Ayemi and Atanda (Eds) managing invention in Nigeria Educational System P. 123 - 130 Oyo Nigerian Association of Educational Administration and Planning (NAEAP). 
Amoor, S.S.(2008). Integrating entrepreneurship education into business education curriculum in Nigerian universities. Zariu Journal of Liberal Arts, 2(2). Retrieved from http://wvvl.abu.edu.nO/publications/20ir08-24-094933 4831 .doc.

Anekwe, J.U. \& Abraham, L.N. (2009). Assessment of resources management for effective entrepreneurship education in An am bra state secondary schools. African Journal of Educational Research and Development, 3(2), 269-281.

Anugwom, G.A. (2007): Entrepreneurship in Nigeria. Principles and Practice. Lagos: Computer Edge Published.

Anwor, O. O. (2002): Reviving interest in education in the South-East Zone'of Nigeria. A paper presented at the First Annual South-East Education Summit held at NnamdiAzikiwe University, Awka, on $15^{\text {th }}$ and 16 May, 2002.

Anyakoha, E.U. (2006): Entrepreneurship education and wealth creation strategies Nsukka: Great AP Express Publishers.

Anyanwuocha, R.A.I. (2001): Fundamentals of Economics, Onitsha. Africana - Fep Rub.

Ltd. Anyaogu, R.O. (2007), Work ethics among academic staff in tertiary institutions in State. Imo State University Owerri: Unpublished dissertation.

Anyaogu, R.O. (2009). Managing entrepreneurship education at tertiary level: A panacea to unemployment. African Journal of Educational Research and Development, 3(2), 99-107.

Ayodele, J.B. (2006): Obstacles to entrepreneurship development in Nigeria in F. Omotosho, T.K.O. Awko, O.I., Wai a-A we and G. Adaramola (Eds). Introduction to Entrepreneurship Development in Nigeria. AsoEkiti, UN AD Press.

Bane, N.P. (2007). Teaching skill related subject Education Review, 5: 28-39. Bellingham, J. (2007): Academic Dictionary of Education NewDelhi: Tata Magraw Hill. Brown C. (2000): "Entrepreneurial education Teaching guide". Kansas City. M.O. Kauffman.

Cherwitz. M. (2006): Entrepreneurship and Economic growth. An inductive survey to specific topics. University ofNamir http:/www Spea Indiana edu/lids/pdfholders/IDSIS.

Chukwuma, R. and Nwaham C.O. (2007): Establishment and Management of Private Universities in Nigeria. The Trend, Problems and Challenges, Access, Equity and Quality in Higher Education. Journal NAEP Publication.

(Combs, P.H. (1985): The world crisis in Education: The view from the eighties. New York: Oxford University press.

Commission Communication (2006): "Fostering Entrepreneurial Mindset through education and learning" Co mm 33 final.

Consortum for entrepreneurship education (2005): Criteria for youth entrepreneurship education, $f$ Retrieved from file http:/www-google com. on 23/6/2013.

Daile, T (2010)What is an Entrepreneur? http://www/business notes, com/choosing/waht'shtml 27/5/10.

Ejiogu, A. (1997): The changing fortunes of higher Education in Nigeria in A. Ejiogu and K. Ajayi (ed) Emergent Issues in Nigerian Education 2 Lagos. University consult pd $117-132$.

Ekpo, A. (2005): Managing a Federal University in Nigeria. My (Experience at university of Uyo $2000-2005$ Uyo. University of Uyo.

Ekwueme L. Ofoha D, Uchegbu C, Anyikule B and Nkemdilim M. (2009): A critical appraisal of the mode of implementation of Nigerian School Curriculum: Toward Socio-economic Empowerment of youth, wwwgogle.com.

Etonyeaku, E.A.C. and Ajala, E.G. (2010): Youth empowerment through skills development and entrepreneurship education in Nsukka Education zone of Enugu State. International journal of Education Research 10:3, $133-144$.

Etor, R., Akpama, S.L, Akpan, C.P. \&Etor, C.R. (2009). Higher education and youth preparation for entrepreneurship: A focus on functional education. Journal of Educational Review, 2(3), 313-318

Ezeuwa L. and Ani I.P.: Assessing Students' Perceptions of Entrepreneurship Education in Enhancing selfemployment for Economic growth in State College of Education in South-East Nigeria. Journal of Curriculum Studies. Vol. 19. No 4 (September 2012).

Fagbamiye, E.G. (2002). Universal Basic Education: Mobilizing resource for successful implementation. In: Ajayi, T. adipe, 3.0 Ojedcle, P.K \&Oluchukwu, E.E (eds). Planning and administration of Universal basic Education (USE) In Nigeria. 
Fajemirokan, S.O. (1999). The relationship between academic performance of students and material resources. Journal of Educational Psychology, 52: 23-36.

Federal Government of Nigeria (2004): National Policy on Education, Nigeria. Federal Republic of Nigeria (2013). National policy on education. Lagos: NERDC.

Gabadeen, W.O. \& Raimi, L. (2012) Management of Entrepreneurship Education in Nigerian Higher Institutions: Issues, Challenges and Way Forward. Abuja International Press.

Ojefo, S. Ade (2012): A hand book on Entrepreneurship Development in Nigeria, Ekpoma, Emmansco printers.

Okafor. R.G. \&Onwumere, J.U J. (2012). Issues and challenges in enhancing efficient entrepreneurial accounting education in Nigerian Universities. Developing Country Studies, 2(11), 220-227.

Okebukola, P.A.O. (2004): Curriculum Implementation in Nigeria, strategies for the $21^{\text {st }}$ century in Noah, A.O.K., Shonibaare, D.O. Ojo, A.A. and Olujuwon, T, (Eds) Curriculum Implementation and Professionalizing teaching in Nigeria. Lagos Central Educational Services.

Okoh, J.N. (2009): Providing entrepreneurship education at the secondary education level through science, technology and mathematics (STM) education to meet the challenges of globalization in Nigeria. A paper presented at an International Conference on Globalization. Entrepreneurship and Education held at University of Nigeria Nsukka.

Okorie, J.U. (2000): Developing Nigerian's workforce Calabar. Macnky Environs Publishers.

Okoro, O.V. (1993). Inadequacy of resources and problems emanated. Journal of Personnel Administration, 10:54-62.

Oku, O.O. (2012). Revitalizing Nigerian university education through entrepreneurship education: The leadership imperatives. www.cceam2Q 12.com/ presentation.....780....

Okunamiri, P.O, Ajoku, M.U, Ndom-Uchendu, M.N (2003): Human Resource Management and Students' Academic Performance in Business studies of subjects in Junior Secondary Schools in Abia f State in Nvvosu, H.I.O. Afianmagban B.E, Nwokocha, L.K and Nwachukwu, R.O. Salient Issues in $21^{\text {sl }}$ century Niferia Education Owerri. WPBN Publisher.

Okwudibia, 2010: Entrepreneurship Education principles and practice in Nigeria, Ekpoma, Emensons Printers. 